\title{
The Sweetest Dream: Lessing, Zimbabwe and Catholicism
}

\author{
ANTHONY CHENNELLS \\ Professor Extraordinaire, \\ Department of English, University of Pretoria, Pretoria, 0002, South Africa. \\ E-mail: intunzi2@gmail.com
}

In her later work Lessing refers frequently, if in passing, to Roman Catholicism often as part of her growing interest in spirituality which began while she was writing The Golden Notebook. Some of these references are in the accounts of her travels in Zimbabwe but they are also to be found in her autobiographies, reviews and occasional journalism. Because of their frequency she cannot be regarded as entirely indifferent to the church. A valid line of enquiry into Lessing's work asks whether her dislike for the church, formed during her traumatic four years as a young child in the Salisbury convent, remained her dominant impression - or whether in later life she found in Catholicism, particularly in Zimbabwe, an institution that invited more complex responses. An answer is provided in The Sweetest Dream, her last long novel that deals directly with Africa. The novel is partly set in Zimlia, a country that clearly suggests Zimbabwe. It avoids representing Catholicism and traditional spirituality as antagonistic; the complex plotting at its end rejects a confident division between the sacred and the secular and suggests that, although Catholicism is on the whole a force for good, its powers in Zimlia are limited, confronted as the church is by the literal epidemic of AIDS and the power of traditional spirituality. One possible reading suggests that this latter power prevails.

\section{Introduction}

In an 'Author's Note' to The Sweetest Dream, Doris Lessing explains that the novel is a substitute for the third volume of her autobiography and that in it she has tried to capture "the spirit of the Sixties', although some of the events take place decades later.* This is particularly true of those parts of the novel that are set in Zimlia which, if it is read as Zimbabwe (and it is difficult to ignore Zimbabwe as a referent), belong to the late 1990s after the Zimbabwean economy began to collapse but before the land redistribution was set in motion. The violent invasions of white-owned farms which in Zimbabwe began in 2000 are 
still ten years in the future in the narrative moment that marks the novel's end. ${ }^{1}$ The dream of the title is of worlds gentler and more just than any we have known, which for much of the twentieth century political utopians imagined as the product of revolutions. In 1940s and 1950s they may have been proposed to Lessing by versions of communism. In 1960s, they are sometimes the hopes that are settled on Africa's newly independent nations emerging in the wake of Europe's empires.

At the novel's beginning, Soviet-controlled communism no longer has the power to shape how the future can be imagined. Yet Soviet dogmas and the labels, loyalties and condemnations are given a continuing authority through the character of Johnny Lennoxson, husband, father and step-father to the generations that inhabit the Hampstead house central to the London sections of the novel. A humane contrast to the imagined global community of Johnny's polemics is the community created and maintained in the same house by Frances, his first wife, around an abundant and hospitable table where she nurtures the Lennox family and their friends. Although most of them despise Johnny's political posturing, they are through him exposed to the proliferation of groups and conferences that promote whatever progressive cause is currently fashionable.

One of these is the war for Zimlia's independence. Its arrival is the occasion for tearfilled rejoicing in London, although the novel cautions that 'Victory celebrations after a war do not have much to say about the dead soldiers'. ${ }^{2}$ The rhetoric appropriate to such occasions transforms the war dead into "the dead comrades "who made victory possible" and "the acclamations and the noisy singing are designed to make the victors forget about[...]grave[s] so shallow the jackals have got there, scattering ribs, fingers, a skull. Behind the noise there is

\footnotetext{
* I am grateful to Tim McLoughlin, Ranka Primorac and two anonymous readers for their comments on an earlier version of this article.

${ }^{1}$ D. Lessing, The Sweetest Dream ((London, Flamingo, 2001), p. 456.

${ }^{2}$ Ibid., p. 233
} 
an accusing silence, soon to be filled with forgetfulness' ${ }^{3}$ If this novel comprises several layers of political engagement, then one of them is surely a rebuke of that forgetfulness and a reminder of failed dreams and betrayed hopes. By the narrative's end, when Zimlia has largely replaced London as its setting, readers are reminded that the African dead do not easily allow themselves to be forgotten. Several years into Zimlia's independence, its corrupt leadership is explained by a failure to " "bury the dead of the war[... .] And you know if we do not bury our dead according to [African] customs they will come back and curse us". 4

In all her political writing and particularly her African writing beginning with $A$ Ripple from the Storm, Lessing registers a deep mistrust of theory (which can deny experience both its particularity and its dynamic unpredictability) and of political rhetoric (which can serve the teleology of some remote future while claiming certainty for choices made in the present). In the celebrations of Zimlia's independence in The Sweetest Dream, the sense of political achievement is palpable but the exuberance is checked by a sobering thought. Both in Zimlia and in London the leaders are 'planning how to make real the sweet dreams that kept them going for years'. ${ }^{5}$ Only through a successful state will the dreams become real. As the novel takes us from Zimlia as idea to Zimlia as realization, its failure as a state is evident: the ruling party and political class are removed from and indifferent to the rural majority and the economy is increasingly dependent on foreign aid. ${ }^{6}$

A perspective that allows us to register the extent of this failure is provided by $\mathrm{St}$ Luke's - the Catholic mission at Kwandere ${ }^{7}$ where Johnny Lennox's daughter Sylvia, a convert to Catholicism, serves as a mission doctor. How the church is institutionally

\footnotetext{
${ }^{3}$ Ibid.

${ }^{4}$ Ibid., p. 419

${ }^{5}$ Ibid., p. 234

${ }^{6}$ An alternative reading of The Sweetest Dream could be as one of the cluster of novels that analyse the failure of Zimbabwe's independence. This now constitutes a considerable body of literature in the post-independence Zimbabwean canon.

${ }^{7}$ Sometimes spelt 'Kwadere'.
} 
embodied in Zimlia in shown via Sylvia's growing awareness of what Catholicism could mean in this context. The mission's hospital, school and church are involved in the country's many problems as these are manifested at a local level. As it heals, teaches, and feeds, the mission provides an alternative community to the scant offerings of the state, recalling Frances Lennox's hospitable table in the Hampstead house.

\section{Lessing and the Salisbury convent}

When Lessing died I was struck by how often her obituaries mentioned her convent education. Helen T. Verongos stands for many when she notes, in The New York Times, that 'She was sent to boarding school and then to a convent school' which 'turned her into a Roman Catholic, but her conversion was merely a stop on the way to atheism'. ${ }^{8}$ In fact, the convent was a boarding school which Lessing went to for four years before going for a further two years to Girl's High School which was also a boarding school and which she left when she was fourteen. She never became a Roman Catholic. There were more Protestants at the convent than Catholics and the nuns made no attempt to covert the former. Only the atheism at the end of Verongos's sentence is correct, and even that was to be replaced by forms of theism fairly early in Lessing's life. The best obituaries ${ }^{9}$ mention the most interesting fact of her education: with only six years of formal schooling, she was in effect an

\footnotetext{
${ }^{8} \mathrm{H}$. Verongos, 'Doris Lessing novelist Who Won the 2007 Nobel Is Dead at 94', New York Times, 18, November, 2013, available at http://www.nytimes.com/2013/11/18/books/doris-lessing-novelist-who-won-2007-nobelis-dead-at-94.html?partner=rss\&emc=rss\&smid=tw-nytimes, retrieved on 14 December, 2013. Similar information appears in Danica Kirka, 'Doris Lessing Obituary' (1919-2013) available at http://www.legacy.com/ns/doris-lessing-obituary/168075618, retrieved 10 January, 2015. Kirka's article for Associated Press was syndicated in several papers in the United States including the Boston Herald, Pittsburg Courier and Buffalo News. Lessing's entry in Wikipedia is another inaccurate account of her education.

${ }^{9}$ These include Peter Guttridge, 'Doris Lessing: Nobel Prize Winning Author Whose Work Ranged from Social and Political Realism to Science Fiction', The Independent, $25^{\text {th }}$ August, 2015; Lorna Sage, 'Doris Lessing Obituary', The Guardian, $17^{\text {th }}$ November, 2013 available at http://www.theguardian.com/books/2013/nov/17/doris-lessing (revised after Sage's death), retrieved 10 January, 2015; and Patricia Sullivan, 'Doris Lessing, Nobel Winning Writer Dies at 94', The Washington Post, $17^{\text {th }}$ November, 2013 available at http://www.washingtonpost.com/local/obituaries/doris-lessing-nobelwinning-writer-dies-at-94/2013/11/17/2bf4ad6-4fa2-11e3-a7f0-b7, retrieved 10 January, 2015
} 
autodidact. Her parents encouraged her to read and saw to it that parcels of books arrived regularly on their farm.

Although Lessing remembers educated women among the nuns, ${ }^{10}$ her principal recollection of the convent is the religious art which hung in the junior dormitory. A painting of the Catholic devotion called the Sacred Heart dominated the room. Lit at night by red lights, it seemed luridly to confirm the words of the departing nun who, leaving the children for the night, promised them death and hell-fire as just punishment for their wickedness. Lessing's recollections of the other paintings in the dormitory are of gruesome martyrdoms and 'all relish in blood and torture'. ${ }^{11}$ The children found different ways of distancing themselves from these horrors. For the Protestant girls, there was a saving scepticism: "'It's only Catholic," [the older girls] would say, "we don't believe all that". ${ }^{12}$ The Catholic children had a whole range of fetishes protecting them: 'rosaries, holy pictures and bottles of holy water'. ${ }^{13}$ If the nuns made no attempt to convert the Protestant girls, '[t]hey did not need to. The atmosphere of magic and mystery was enough' ${ }^{14}$

The nearest Lessing comes to the conversion of some of her obituaries is to admit that 'Most of us at one time wanted to be Catholics, simply to be like the Catholic girls, who dipped their fingers into the holy water stoups and curtsied at the statues of Christ and the Virgin' and whose lives seemed to be regulated by the Angelus bells from the nearby Cathedral and the feast days of the Catholic church. These are the seductions of the arcane, the 'allurements of the forbidden'. ${ }^{15}$

\footnotetext{
${ }^{10}$ D.Lessing, African Laughter: Four Visits to Zimbabwe (New York, HarperCollins, 1992), pp. 163-4; Under My Skin, Volume One of My Autobiography to 1949 (New York, HarperCollins, 1994), p. 95.

${ }^{11}$ Lessing, Under My Skin, p. 91.

12 Ibid., p. 92

${ }^{13}$ Ibid.

${ }^{14}$ Ibid., p. 93.

${ }^{15}$ Ibid.
} 
In a characteristically ambiguous recollection of her mother, Lessing remembers 'the exact moment when I shed religion and God: it was when my mother, upset that her child had a crush on the Virgin Mary[...] recited a list of the misdeeds of the Roman Catholics, all of which could be matched by the Protestants', and the child heaves the burden of religion from her shoulders and replaces it with 'the brave stoicism of atheism' ${ }^{16}$ Her spell at the convent had made her an atheist, wary of the power of collective hysterias and destructive conformisms, determined to take control of who she was.

\section{The first stages of Lessing's spiritual quest}

The convent was not Lessing's last contact with Catholicism before her visits to Zimbabwe in the 1980s. When her mother announced that she was coming to England to look after Lessing and her son Peter, Lessing's defence against this intrusion was to take herself off to a therapist. At the time Lessing was a communist and 'communists did not go "into analysis", for it was "reactionary" by definition'. ${ }^{17}$ Her therapist, Mrs Sussman, the inspiration for Mother Sugar in The Golden Notebook, was a Jungian and a Jewish convert to Roman Catholicism. Mrs Sussman refused to talk about her own conversion except to tell Lessing 'that Roman Catholicism ha[s] deeper and higher levels of understanding, infinitely removed from the crudities of the convent' ${ }^{18}$

Jungian therapy provided Lessing with glimpses of a world of presences inhabiting levels of being with the capacity to transcend a teleological concept of history which had enabled her communist groups in Rhodesia and London confidently to identify the social forces that would determine the future. As she was taught to recognise and name these figures from her dreams, Lessing finds herself 'instinctively happy with the idea of archetypes, rising

\footnotetext{
${ }^{16}$ D. Lessing, Walking in the Shade, Volume Two of My Autobiograpy, 1949-1962 (London, Flamingo, 1998), p. 318.

${ }^{17}$ Ibid., p. 35.

${ }^{18}$ Ibid.
} 
from literature and myth like stone shapes created by Nature out of rock and mountain'. ${ }^{19}$ She hated the labels that are attached to figures or situations partly because they reminded her of communism's habit of 'labelling of everything and [its] vindictive and automatic stereotypes'. ${ }^{20}$ In The Golden Notebook, Anna Wulf imagines Soviet reviews of her novel, Frontiers of War. The reviews agree on the absence of typicality in her depiction of blacks in Central Africa; the reviewer in the 'Soviet Journal for Literature for Colonial Freedom' detects in the novel 'Freudian influences[...] an element of mysticism' and advises the author to learn 'how to make mankind laugh at what is already dead, backward, outmoded by history'. ${ }^{21}$ These critiques reveal their authors' dogmatism with regard to what should be contained within what Lessing refers to (in Walking in the Shade) as "the "package", 22 -in this case, the prescriptive notion of what socialist art is obliged to address or exclude.

The most significant item in the ideological 'package' that The Sweetest Dream rejects (and this is an item that is not the sole property of socialism) is described in Walking in the Shade as 'philosophical materialism, the God-is-dead, Science-is-king materialism'. ${ }^{23}$ Anyone in Lessing's London of the 1970s who does not subscribe to this 'is patronized as feeble minded and a coward' and 'a sneer, implicit or overt' accompanies the proclamation that "“I do not understand people who believe in God"". ${ }^{24}$ She remembers the time when she made the same sort of remark and '[her] smugness and [her] feeling that she was saying something original that had cost thought'. ${ }^{25}$ Only when she finally completed The Golden Notebook did she grow beyond that stage and (as she expresses it) found that she had written

\footnotetext{
19 Ibid., p. 36.

${ }^{20}$ Ibid.

${ }^{21}$ D.Lessing, The Golden Notebook (London, Michael Joseph, 1962), pp. 381-2.

${ }^{22}$ Lessing, Walking in the Shade, p. 316.

23 Ibid.

${ }^{24}$ Ibid., p. 317.

${ }^{25}$ Ibid.
} 
her 'way out of the package'. ${ }^{26}$ In refusing to continue with an easy conformity to unexamined atheism, she had to come to terms with a complexity that she had not been educated into recognising, let alone analysing. 'I had so thoroughly reached the end of a whole spectrum of ideas, thoughts and feelings that the world I had excluded as "impossible", as "reactionary", was surrounding me, pressing in, making its claim'. ${ }^{27}$ And yet here was a 'world of ideas and belief that I had scarcely ever heard of, let alone been seriously introduced to'. ${ }^{28}$ Lessing reminds us that '[i]n our own culture, at its heart is the inner spiritual tradition of Christianity' attested to by the great mystics like John of the Cross, Dame Julian of Norwich and the unknown author of The Cloud of Unknowing. ${ }^{29}$

In her middle life Lessing met Muriel Spark who had also spent the Second World War in Rhodesia but who was a Catholic convert. One explanation for Spark's conversion is a remark that Lessing quotes: “"The churches were so much more cheerful than others, so full of colour, glitter, incense and images", ${ }^{30}$ No hint here of an iconography that moves between the sadistic and the lugubrious, threatening and beguiling. Lessing sees this as a 'sparkle of aesthetic enjoyment' that non-believers can and do share but, echoing Mrs Sussman, she wonders whether Spark found within Catholicism the wisdom of the centuries that gave her 'opportunities for ironic comment on our hypocrisies' or whether in converting to Catholicism 'like was calling to like, for the wise intelligence in [Spark's] work does put her in the company of writers who share the long perspectives of Rome'. ${ }^{31}$

\footnotetext{
${ }^{26}$ Ibid.

${ }^{27}$ Ibid., p. 319.

${ }^{28}$ Ibid., p. 320.

29 Ibid.

30 D. Lessing, “"Now You See Her, Now You Don't"', in D. Lessing, Times Bites: Views and Reviews (London and New York, Fourth Estate, 2004), pp. 113-29, p. 119. This was originally written for a Festchrift for Spark that does not appear to have been published.

${ }^{31}$ Ibid., p. 118.
} 
Lessing's account of her spiritual quest is moving because it is, at least in part, an account of intellectual isolation and this has its fictional representation in Sylvia Lennox's conversion in The Sweetest Dream. Her family regards Sylvia's conversion with indifference or incredulity. Until Lessing discovered the writings of Idries Shah ${ }^{32}$ and met him, no-one among her many London acquaintances could share her growing awareness that an important dimension of human consciousness had always been absent in her life. Her search was for processes of discernment that would allow her to identify that what she had perceived was a genuine illumination. Hers is a society where the word 'mysticism', if it is used at all, provokes discussions of 'ghosts, poltergeists, reincarnation, fortune-telling, the I Ching, UFOs, horoscopes' - 'exciting experiences of one kind or another' although Lessing observes that any 'serious spiritual discipline' regards "“supra-normal” phenomena[...] as distractions, as irrelevancies'. ${ }^{33}$ To that list of popular forms of mysticism, Lessing could quite easily have added the Roman Catholicism that she encountered through the paintings and statues of the Salisbury convent which at its best give the spiritual a dramatic and physical immediacy and at its worst is a substitute for thought and any feeling except fear. In The Sweetest Dream, Sylvia Lennox traces some of the stations on Lessing's own path. She has to move beyond her father's dogmatic socialism and her youthful engagement with popular mysticism, but in the novel, Sylvia's conversion to Catholicism replaces Lessing's involvement with Idries Shah. On the Zimlia mission, Sylvia discovers the sort of Catholicism and the dimensions of

\footnotetext{
32 Idries Shah (1924-1996) was a prolific author who sought to make Sufi traditions accessible to Western audiences. Lessing knew him as teacher and friend and a Daily Telegraph article about their relationship which she wrote after his death was reprinted as 'Summing Up: When Idries Shah Died', in Lessing, Time Bites, pp. 357-68.

${ }^{33}$ Lessing, Walking in the Shade, p. 324. Although Lessing dismisses these practices in her autobiography, Jenny Diski, in one of the recent accounts of her relationship with Lessing, mentions Lessing practicing yoga, 'standing on her head for twenty minutes or so a day' and spending Thursday evenings gazing at a mandala. For Diski, Sufism is made up of 'slight tales and received wisdom'. ('In Gratitude', London Review of Books, 7 March, 2015, pp. 29-32, p. 30.) Lessing's lonely search, which I find moving, Diski writes as eccentric or even unhinged.
} 
religious experience that are arguably related to what Lessing had glimpsed in her Zimbabwean journeys-particularly in 1988 and 1989.

Someone like Lessing, who had refused to observe the unquestioning discipline of the Communist Party, would have had little inclination to identify with any organisation obsessed with monitoring and penalising dissidence as Catholic institutions were for much of her life. Part of the attraction Idries Shah had for her was that he was not interested in fixed truths and their systems because he recognised that "“a school is a temporary thing, which will be dismantled as soon as its work is done"" since it is always "“carefully designed for the needs of 'the time, the place, the people"', ${ }^{34}$ The spiritual that Shah enables her to discover is dynamic — de pendent on place and time, and thus encountered differently at different periods and locations.

In his work, Shah describes formal religions such as Catholicism 'as "the screens" the light falls through'; or as a 'vehicle [whose] expression, rituals, moral and other teachings, are designed to cause certain elevating effects, at a certain time, upon certain communities'. But he also warns that if these are the means, they can 'bec[ome].... for the shallow the end, and the vehicle bec[ome] the idol'. With the word 'idol' Shah is suggesting a fateful stasis which only 'the man of wisdom, not the man of faith or intellect', can give the gift of movement. ${ }^{35}$ For both religions of The Sweetest Dream, Catholicism and traditional African spirituality (Shona if one has made the Zimbabwean connection), reality is imbued with the timeless but since both are also manifested in complex and often authoritarian social organisations - the legalism of Rome, or submission to the particularities of Africa's cultural traditions - the timeless is easily masked by the demands of the present. In the novel Sylvia

\footnotetext{
${ }^{34}$ D. Lessing, 'The Sufis', in Lessing, Times Bites, pp.254-72, p. 264. First published in Books and Bookmen. 35 Ibid., p. 265.
} 
has to re-experience the elevating effects of her particular version of Catholicism without the aid of elaborate ritual and the rigours of orthodoxy. In the end she may be unsuccessful.

\section{Catholics in Lessing's African Laughter}

During her second visit to Zimbabwe, recounted in African Laughter, Lessing meets Sister Dominica, a Dominican nun, who is to reappear as Sister Molly in The Sweetest Dream. ${ }^{36}$ The only distinguishing feature of Sister Dominica's dress is a silver cross. She finds recruits from all over the world to work in remote rural schools where trained teachers are in short supply. In African Laughter, Lessing describes her and her companion as 'feminists, critical of the male authority of the Church and the Pope'. ${ }^{37}$ Unconventional, accustomed to driving by herself all over the country (often along abominable roads) and engaging with a diversity of classes and races, Sister Dominica has little in common with the nuns of the genteel convent to which Lessing's mother sent her. ${ }^{38}$ Sister Dominica takes Lessing to visit the Jesuit-run Silveira House which was originally founded in Rhodesia in 1964 to train community workers (especially those in the trade unions). Its projects included programmes for rural development. ${ }^{39}$ During the liberation war, Silveira House had an uneasy relationship with the Rhodesian police, as two of Robert Mugabe's sisters worked there. In the months after his release from detention and before he crossed into Mozambique, Mugabe visited Silviera. ${ }^{40}$ The security forces were right to be suspicious. If priests stayed on their missions

\footnotetext{
${ }^{36}$ D. Lessing, The Sweetest Dream, p.347. Sister Molly runs an organisation similar to Sister Dominica's mentioned in African Laughter, p.163. When Lessing gave Sister Dominica a copy of The Sweetest Dream, she told her she would find someone familiar in the novel. (Personal communication of Sister Dominica Seigel O.P.) She is perhaps 'the very minor character' based on an actual person referred to in the Author's Note.

${ }^{37}$ Lessing, African Laughter, p. 163.

${ }^{38}$ Lessing, Under My Skin, p. 89, explains that 'The Convent, like convents in Britain, was supposed to be more genteel than the High School. I am always meeting women who were sent to convents for the same reason'. ${ }^{39}$ D. Harold-Barry, Knocks on the Door: Silveiria House: the First Forty Years, 1964-2004 (Harare, Silveira House, 2004), pp. 15-19 summarises the work of Silveira House in forming trades unions. Harold-Barry, pp. 1926, describes some of the agricultural initiatives that Lessing saw.

$40 \mathrm{~J}$. McLaughlin, On the Frontline: Catholic Missions in Zimbabwe's Liberation War (Harare, Baobab, 1996), p. 26. Harold-Barry's Knocks recalls that Mugabe used a meeting at Silviera House to provide 'a crystal clear
} 
during the Liberation War, they had to have contact with the guerrillas and Silveira House was no different. A Jesuit priest who was at his mission throughout the war told Lessing of 'the boys' (as the guerrillas were referred to in Shona) dropping in "“when the Security Forces were looking the other way. They wanted an evening of being ordinary[...]We had a meal, they drank, they danced[...]They taught me how to jive. They were very young men, boys some of them, sixteen, seventeen"', 41

In her account of the various initiatives of Silveira House, Lessing registers a peopleoriented Catholicism which involves complex interactions between the Church, the land and the people. ${ }^{42}$ At Silveira, she saw a sculpture workshop for the unemployed; a shed financed and built by the community 'in the impetuous days of Liberation [when] everything seemed effortlessly possible ${ }^{43}$ and which would provide storage for seed maize and then for the harvest, a place where health workers could run workshops and where political meetings and educational classes could be held. She knew it was just a shed but redolent with possibilities for an inspired community.

Lessing brings to some of these projects a scepticism bred not from cynicism but rather from a mythic imagination that recognises that people have more complex needs than those that are simply practical. One of the Silveira House Jesuits, who is 'an internationally known expert on alternative technology[...]

\footnotetext{
analysis of the situation at the time' and that he was one of several nationalist leaders who helped 'the "civics" programme bec[o]me a thinly disguised forum for political education'.(p. 6)

${ }^{41}$ Lessing, African Laughter, p. 396.

${ }^{42}$ Silveira House was strongly influenced by the theology of liberation which was being developed in Latin America at the time Silveira was founded. Peruvian Gustavo Gutiérres, sometimes seen as the father of this theology, said of it in 1968 that 'we are passing from a theology that concentrated excessively on a God located outside this world to a theology of a God who is present in this world' ('Toward a Theology of Liberation', in A. Hennelly, S.J., (ed), Liberation Theology: A Documentary History (Maryknoll NY, Orbis Books, 1990), pp. 62-76, p. 70. Later in this article Gutiérres observes that 'As Marx had clearly seen, work as a humanizing element normally tends through the transformation of nature to construct a society that is more just and worthy of human beings' (p. 72). When Lessing visited Silveira House, the Vatican had begun to curtail this theology criticizing in particular its dependence on Marxist analysis.

${ }^{43}$ Ibid., p. 167.
} 
with saving the world from our stupidities, ${ }^{44}$ has developed a system of feeding animal dung and the household waste of poor rural homesteads into pits to produce fertilizers and methane gas. Despite the energy that has gone into this system, Lessing notices that in one of the huts, cooking is still being done on a smoking log with the gas pipe unused. Some atavistic social needs are more powerful than the practical alternatives that the priest's enthusiastic creativity provides. A solar stove, another invention that the expert tries to promote, has 'no emotional appeal. You can't sit round a solar stove gossiping'. An ancient collective memory competes with the rational presence of the methane pipe: the log 'has been burning in the middle of the cave, a hut, a hall for - how long? Thousands of years? Millions? The centre of communal life'. ${ }^{45}$

For Lessing, what is important is not these failures to register the primary needs, but that an institution like Silveira House has engaged the resourcefulness of local people. This church institution is for her an effective agency of social empowerment because the creativity of an artist, or a peasant farmer or an individual homestead is developed as far as it is possible on its own local terms. ${ }^{46}$ She is also aware that priests and nuns- representatives of the Church — were with the people during the liberation war and that they can understand that the traumas of those violent years continue to manifest themselves in different ways. A Jesuit remarks that, following the war, "'The Feast of All Souls has a new meaning. The souls are the souls of the dead fighters, killed in the war and left unburied' ${ }^{47}$ But Lessing also notes, without further comment, that former Freedom Fighters have made it their duty to bury 'with

\footnotetext{
${ }^{44}$ Ibid., p.165. Harold-Barry, Knocks on the Door, pp. 39-40, puts these alternative technology initiatives in the larger context of Silveira House's projects.

${ }^{45}$ Lessing, African Laughter, p. 165.

${ }^{46}$ In the 1985 Massey Lectures which Lessing delivered for the Canadian Broadcasting Corporation, she remarks that for 'two thousand years Europe was under a tyrant-the Christian Church-which allowed no other way of thinking'. The churches are '[n]ow...amiable, often orientated to work that is indistinguishable from social and charitable work'. Prisons We Choose to Live Inside (New York, Harper \& Row, 1987), p. 25. The latter assessment of the contemporary church can be discerned in her accounts of Silveira House.

${ }^{47}$ Lessing, African Laughter, p. 389.
} 
appropriate rites' their comrades. ${ }^{48}$ 'It is believed by many that the country is full of dissatisfied and vengeful ghosts, and it is they who are responsible for Zimbabwe's many problems' ${ }^{49}$ Once, she would have dismissed both the priest and the former guerrillas as people locked into the delusions of the past. Yet the Lessing who emerged from writing The Golden Notebook with awareness of her own limitations now directs her contempt at such facile labelling. This Zimbabwean anecdote anticipates the restless dead that are a silent presence in The Sweetest Dream, both at the moment of the Zimlian independence celebrations and at the end of the novel.

\section{The Sweetest Dream}

It was always unlikely that The Sweetest Dream - with its often satiric depiction of the collective obsessions of the decades it covers-would get an enthusiastic critical reception. Hywel Williams's review in The Guardian wrote of it as 'the savage cartography of a once fondly imagined land by one who was there. This is emotion recollected in hate'. The review calls the novel 'a truly reactionary work in the limited sense that the author still stands at too close a remove to the object of abomination. In the full force of her reaction, she parodies and stereotypes' ${ }^{50}$ Parody and stereotype are, of course, established and expected aspects of a

\footnotetext{
${ }^{48}$ Lessing does not indicate what would constitute 'appropriate rites' but they would almost certainly be those from Shona burial practices. The burial of the war dead is discussed in T. Shoko, "My Bones Shall Rise Again": War Veterans, Spirits and Land Reform in Zimbabwe, www.asc/eiden.nl/-ASCWebsite.

${ }^{49}$ Lessing, African Laughter, p. 389.

${ }^{50} \mathrm{H}$. Williams, 'The Dream is Over' The Guardian, 22 September 2001. A more recent public mention of the novel is by Jenny Diski, 'My Word-Untangling Machine' The London Review of Books, 19 September, 2015, pp. 27-28, p. 27. In many of her recent LRB articles, Diski's representation of Lessing has been ambivalent: the older woman is seen as both self-serving and saviour. Diski's references to The Sweetest Dream follow a similar pattern: her comments on the Author's Note acknowledge Lessing's generosity in foreswearing to write a third volume of her autobiography (realising the hurt she could cause), as well as the threat contained therein (because she could, as long as she herself was alive, go back on her word). Her brief article does not mention the text of The Sweetest Dream at all, nor does it provide any evidence that Diski has read further than the Author's Note.
} 
satirist's discursive strategy. As the superlative 'Sweetest Dream' suggests, there are many dreams the novel satirises: the current version of Marxism that will save the world; the teleological narratives of aid agencies, which both diagnose and prescribe remedies for the ills of a country and a continent; the betrayed aspirations of Africa freed from colonialism; and a Catholicism rigorously self-righteous in its belief that it alone has access to truth. Williams' accusation — that Lessing stands 'at too close a remove' to her subject—ignores an important feature of Lessing's narrative method. She distances herself from 'Zimlia' by seeing the country partly from the perspectives of a Catholic mission, with a nun, a priest and a convert doctor as focalizers-whose perceptions Lessing can represent without necessarily sharing.

Through the character of Sylvia, the novel traces another and more important process. Sylvia slowly comes to understand 'how deeply the lives of the black people she lived among were embedded in superstition'- which she wants 'to understand [...]not to make what she thought of as "clever intellectual remarks"" at the expense of 'simple' people, that would amuse her intellectual London family. ${ }^{51}$

Involved in Sylvia's curiosity is one aspect of her conversion: 'Someone subscribing to the miracles of the Roman Catholic Church should not accuse others of superstition [...][and] it was far from a criticism of the religion [of the Church]'. ${ }^{52}$ The pronoun 'it' is left without a clear referent here, allowing the passage to be related to either subscription to miracles, or to 'superstition' or both. The ambiguity of the sentence shifts readers' textuallyproduced certainties away from endorsing conclusions guaranteed by logic and reason. The Church has to mean more than its welfare work. As a teenager, Sylvia enthusiastically extracts from the rag-bag of available mysticisms 'her sun-sign, the I-Ching and her probable

\footnotetext{
${ }^{51}$ Lessing, The Sweetest Dream, p.350.

${ }^{52}$ Ibid.
} 
aura ${ }^{53}$ However unsatisfactory these popular mysticisms are, they have similar effects on the young woman to those that Lessing herself experienced, when she became aware of a spiritual world demanding her attention. 'Perspectives and possibilities she had never suspected filled [Sylvia's] whole being, as if it had been quite empty before' ${ }^{54}$ Sylvia becomes a Catholic. The novel initially explains her conversion with the simple statement 'she want[s] to be religious' ;' ${ }^{55}$ we later learn that an account of a young Zimlian, rescued by Jesuits, 'touched her somewhere deep' and drew her to the church. ${ }^{56}$ Only when she has qualified as a doctor and is working at a mission hospital in Zimlia are readers given more information about her conversion. Father Jack, the London priest who instructs Sylvia in her new faith, is a man 'consuming himself with an asceticism that didn't suit him' and 'vigilan[t] against error and sin', who 'st[ands] for priesthood, for the Faith, for her religion'. ${ }^{57}$ She falls in love with him and he is 'not indifferent to her' ${ }^{58}$ The priest, his repressed sexual instincts aroused by an ingénue regarding him with love and awe, is a cameo from a nineteenth-century, anti-catholic novel. ${ }^{59} \mathrm{He}$ is dismissed in a paragraph. The novel is less concerned with the processes of Sylvia's conversion than with the different Catholic imaginary that is revealed to her by Kwandere and the hospital at St Luke's mission, which lacks even the most basic amenities. ${ }^{60}$

\footnotetext{
53 Ibid., p. 126.

${ }^{54}$ Ibid., p. 127.

55 Ibid., p. 155.

56 Ibid.

${ }^{57}$ Ibid., p. 285

58 Ibid.

${ }^{59}$ These conventions are well described in Diana Peschier, Nineteenth-Century Anti-Catholic Discourses: The Case of Charlotte Brontë (Basingstoke, Palgrave Macmillan, 2005), pp 25-69.

${ }^{60}$ St Luke's was partly suggested to Lessing by a visit she and I paid in 1988 to a young doctor working at St Paul's Hospital, Musami, some sixty kilometres from Harare. Anne Renfrew was the only doctor at Musami but the hospital had and still has a nursing staff and other facilities including an operating theatre. These of course appeared meagre to someone living in London but they were not as meagre as those Sylvia confronts. St Paul's was where the Jesuit in African Laughter was taught to jive by the guerrillas. He and a companion had gone to Musami to replace four nuns and three priests who were murdered there in 1977.
} 
Sylvia's impression of the mission when she arrives is more than the shock of the unfamiliar - 'the landscape of an Africa which she was prepared to admire [...] It was alien to her now' ${ }^{61}$ She is there, in part at least, because she is a Catholic, yet 'waves of bitter emptiness attack [] her, and when she look[s] at the crucifix, to get her bearings, [she] fe[els] only that Christ Himself must be surprised to find Himself there'. ${ }^{62}$ This thought is replaced by a sense of shame that she can be 'surprised to find Christ in a place of such poverty'. In the months that follow, while Sylvia does not 'shed her Catholicism, she [is] certainly having to redefine her beliefs'. ${ }^{63}$ At Kwandere, two European church buildings, Westminster Cathedral and Notre Dame, which once were 'everything she loved most made visible' have been displaced by an unadorned brick church where 'the women $\mathrm{g}[\mathrm{e}] \mathrm{t}$ up from their seats, powerfully dance[] their worship, and s[i]ng - oh, beautifully, yes, they d[o] - and it [is] a noisy convivial occasion, like a party'. ${ }^{64}$ Moreover, mass is celebrated in the local language. In place of Father Jack whose 'eyes accuse[] the world around him ${ }^{\text {,65 }}$ is a Father McGuire 'with warm welcoming eyes, and an air of jovial welcome', ${ }^{66}$ an easy going, elderly man who love[s] his food ${ }^{67}$.

The political certainties and easy judgments of the Hampstead house, as much those of her socialist father as of the liberal Lennoxes, have little purchase in Kwandere. At St Luke's, Sylvia soon modifies the scientific certainties of her British medical training and begins to speak with respect of the knowledge of the local n'ganga - traditional healer and spirit medium. He can help, she explains to neighbouring white farmers, in "“cases our medicine cannot reach[...] I say to him, I don't want to meddle in his medicine. I just want[]

\footnotetext{
${ }^{61}$ Lessing, The Sweetest Dream, p. 273.

62 Ibid., p. 275.

63 Ibid., p.285.

${ }^{64}$ Ibid., pp. 285-6.

${ }^{65}$ Ibid., p. 285.

${ }^{66}$ Ibid., p. 279

67 Ibid., p. 285.
} 
his help"' with conditions that can be attributed to spiritual causes. She recalls his talking to patients whom she does not think she can save: "'I don't know what he said, but some of them just got up and walked off-they were cured"”. ${ }^{68}$ As AIDS becomes her primary concern, Sylvia further realises that "“The $n$ 'gangas know more about AIDS [...] than the government people do"'. The local n'ganga is aware of his limitations in the face of the pandemic. He has told her that he cannot cure AIDS but he can treat some of its symptoms. ${ }^{69}$ Lessing writes Sylvia's increasing immersion in the life of the mission as a movement into the complexity of ordinary life in an unfamiliar cultural context, which causes a radical reworking of her sense of self and of her deeply-held beliefs. It is a key part of my argument here that Lessing leaves the ultimate answer to the question about the precise direction of this reworking deliberately unclear.

The redefinition of Sylvia's beliefs is given an institutionally specific meaning when McGuire gets malaria and she nurses him. His room is like hers, furnished with the most modest essentials, and is made of bare brick with a reed ceiling. In her room there is a reproduction of Leonardo's Virgin of the Rocks where the Virgin, the Christ Child, the infant John the Baptist and an angel form a group in a mountainous desert landscape which extends the dominant trope of drought in Zimlia; in the priest's room is another Virgin, a 'conventional representation[] inspired, if distantly, by the Italian Renaissance, blue and white and with downcast eyes, and surely out of place here in the bush? ${ }^{, 70}$ But as Sylvia looks round the room she notices, carved out of local wood, 'a native Mary, a vigorous young woman, was nursing a baby. That was better' ${ }^{71}$

\footnotetext{
68 Ibid., p. 355.

69 Ibid.

${ }^{70}$ lbid., p. 289

${ }^{71}$ Ibid.
} 
In 1965, a document produced by the Second Vatican Council, Gaudium et Spes, proclaimed that 'the Church sent to all peoples of every time and place, is not bound exclusively and indissolubly to any race or nation, any particular way of life or customary way of life recent or ancient' ${ }^{72}$ The immediate consequence of this shift in the church from its Roman centre was the use throughout the global church of vernaculars and local music and dances - the reform of Catholic worship that Sylvia initially finds disturbing in the mission masses she attends. That Father McGuire should use the image of a local woman carved in local materials to represent Mary indicates, for me, another effect of the Council. The novel implies that the Vatican Council was no more than another ideological shift in a decade where old ideologies were dying and new ones were emerging: 'In the Sixties, the tumults of ideology that afflicted the world had taken a local shape in the Catholic Church, in a bubbling unrest' ${ }^{73}$ One of the consequences of these changes was an 'attempt to dethrone the Virgin Mary. The Holy Mother was out'. ${ }^{74}$ Sylvia who becomes a Catholic after these changes 'had never prayed to the Virgin, only to Jesus'. ${ }^{75}$ Yet at the mission the Virgin is present in the 'native Mary', sculpted as nursing mother, and in the print of a version of the Leonardo painting. The narrator comments: 'It could be easy to conclude that this was a religion that worshipped women [...]You could say that the Virgin had slipped through the interstices of dogma by the way of Art'. ${ }^{76}$ This and the following comment suggest that the mythic figure of the Virgin Mother, like all myths, exists in our unconscious, and that art has the capacity to raise them to our consciousness: 'Sylvia had not known that she cared

\footnotetext{
72 Gaudium et Spes, Pastoral Constitution of the Church in the Modern World. Promulgated by Pope Paul VI, 7 December, 1965, Chapter 58. http://www.ourladyswarriors.org/teach/gauspes.htm (accessed 15 August, 2014)

${ }^{73}$ Lessing, The Sweetest Dream, pp. 289-90.

${ }^{74}$ Lessing, The Sweetest Dream, p. 290. The Second Vatican Council sought to recall the Church to its centre in Christ. Inevitably the Council documents ignored popular spiritual devotions and since many of these were Marian devotions, Mary appeared to be 'de-throned' as these devotions fell out of favour. In fact, Lumen Gentium, one of the Council's most innovative documents devotes a chapter exclusively to a theology of Mary. ${ }^{75}$ Ibid., p. 290.

${ }^{76}$ Lessing, The Sweetest Dream, p.290.
} 
particularly for the Holy Mother but did know that she could not live without reproductions of the pictures she loved best'. ${ }^{77}$

On one side of Catholicism is the juridical organisation of the Vatican and the judgmental Father Jack, with confining rules constraining everyday behaviour or dogmas that tell how eternal truths should be known. On the other side there are eternal presences which art speaks for. Art refers not only to the Marian art works but to a worship that is sung (in a non-European language), and danced. Sylvia's journey to a deeper spirituality is a movement away from the authority affirmed in the great Cathedrals which offer cultural safety in their confident assertiveness, and liturgies that have for a European a familiar beauty. Relevant here is Shah's observation, quoted above, that rituals cause 'certain elevating effects, at a certain time, upon certain communities'. But Shah's warning that these buildings and the worship they foster can become ends in themselves is an admonition that St Luke's Mission has no need to heed. Through Father McGuire's encompassing humanity, St Luke's is alert to and tries to accommodate the needs of a remote part of Zimlia.

In the novel's narrative present, cultural vitality is represented through the figure of Sister Molly. When Molly meets Sylvia on her return from London, where she has sourced books for the mission school and medicine for the hospital, Molly is standing outside the airport 'outlined by that brilliance of light that means rain has recently cleared the air'. Under Sylvia's gaze, 'The sunlight dazzled off Sister Molly's cross, shone off her strong brown legs. Healthy, that was the word for her. And healthy was this scene, everything strong and vigorous[...] Sylvia felt herself again[...] London seemed unreal to her: this was real' ${ }^{78}$ Zimlia reveals Sylvia to herself. The novel thus recalls Lessing's recognition of herself when she returned home to Zimbabwe in 1956 and realized that she had never lived anywhere since

\footnotetext{
${ }^{77}$ lbid., p. 290.

${ }^{78}$ Ibid., p. 346.
} 
she 'left the first house on the kopje' that her father built of pole and dagga. Once again, if only for a night, there is 'no barrier [between her] and the steady solemn magnificence of those skies[...] and at immediate intimacy with the soil and its creatures' ${ }^{79}$ But in The Sweetest Dream, it is a nun who has become part of a landscape that responds with vigour to the early rains. Moreover, throughout the Zimlian sections of the novel, we read of Sister Molly's defiance of the institutional church. The novel recognises that, in refusing a conventional submission to the institution, Molly is creating an alternative institutional space in which her creativity finds expression. Zimlia is a stronger society because of her organization that sends well-qualified teachers to rural schools. Sometimes the poverty is too much for these volunteers to take and 'Breakdowns, fits of depression, collapses of all kinds[...][are] a hazard of her work[...] and some sheltered young thing' turns to Molly for consolation and 'find[s] herself rocked on the bosom of the deep' ${ }^{80}$ That extravagant metaphor re-imagines Molly as another variation of the Virgin Mother herself.

For much of The Sweetest Dream, the government in Senga is entirely remote from St Luke's. The mission is too poor to be attractive to ministers and senior civil servants. Some of the new ministers were visitors in the Hampstead house when they were refugees from the settler colony. Now they appear at gatherings for international donor organisations, where 'lesser guests [tell] each other, "Look, there's Global Money.". ${ }^{81}$ The man in charge of Global Money is Andrew Lennox, Sylvia's handsome and urbane step-brother, who visits Kwandere only because Sylvia is there. Yet he finds St Luke's to be a revelation. In Sylvia's meagre room there is a photograph of himself as a younger man- now re-contextualised. The picture shares space with a crucifix that draws from him a scriptural reference: the face

\footnotetext{
${ }^{79}$ D. Lessing, Going Home (London, Michael Joseph, 1956), p. 35.

${ }^{80}$ Ibid., p. 347.

${ }^{81}$ Ibid. p. 297.
} 
before him is of one who 'had not then eaten of the fruit of good and evil' ${ }^{82}$ Andrew, who does not 'suffer from race prejudice', cannot ignore that Sylvia resembles Rebecca, the mission housekeeper, not only because of her sun-darkened skin but in 'certain mannerisms, ways with the face and the eyes' and he wonders 'What was Sylvia doing letting herself go like this? ${ }^{83}$ One answer to his unspoken question comes when the mission housekeeper Rebecca says, on behalf of the village community, "WWe think Doctor Sylvia has been sent by God to us", ${ }^{84}$ If God is present here, it is recognised through someone who in 'letting herself go' has begun to resemble the people among whom she works.

One way of registering Lessing's satire here is to note her alertness to differences of scale. Andrew speaking on behalf of Global Money says that "We shall be directing money-a big loan, to Zimlia", ${ }^{85}$ although when he says this we know enough about Zimlia to understand that most aid money will never reach those whom it is intended to help, and that St Luke's needs are too modest to provide a focus for Global Money. Andrew is part of 'the international crowd' who in Senga 'resum[e] conversations that [may] have been interrupted in Bogota or Benares ${ }^{, 86}$ and will encounter one another again on conferences with titles like "The Perspectives and Implications of Poverty" or "The World's Threatened Ecostructure"". ${ }^{87}$ St Luke's Mission has no place in their debates because their global gaze is blind to local detail. Not only are the aid agencies indifferent to the particularities of Kwandere's distress, but for some of the local politicians too, Kwandere is best left unnoticed, because it represents poverty from which they have themselves escaped. Furthermore, the ruling party's clichés of a successful revolution make it difficult for it to frame a language that admits to the existence of the rural poor.

\footnotetext{
82 Ibid., p. 305.

${ }^{83}$ lbid., p. 307.

${ }^{84}$ lbid., pp.307-8.

${ }^{85}$ Ibid., p.311

${ }^{86}$ Ibid., p. 438.

${ }^{87}$ Ibid., p. 441.
} 
One way of reading The Sweetest Dream is to register repeated patterns of theories that in their broad sweep overlook the nuances and the saving perspectives of the local and the immediate. Global aid agencies propose analyses and solutions that are blind to the details of Kwandere's poverty; Rome's regulations of belief and practice for the Universal Church would be contemptuous of the worship and ritual of St Luke's. These shifts of scale provide a framework for the narrative's ethical standpoint.

\section{The Power of Traditional Beliefs}

The last chapters of the novel bring together as agents in the narrative the corrupt politics of Senga and the AIDS epidemic that is causing deaths easily attributed to witchcraft.

'Witchcraft' is a potent force in the novel, and, as a notion, parallels the ease with which people can be labelled enemies of state and agents of South Africa-which is what happens to Sylvia before she loses her job at Kwandere at the novel's end. Two children who have helped her at the hospital are orphaned by AIDS. But before he dies, their father both curses Sylvia and orders her to take them to England. She calls in the debts that one of Zimlia's ministers owes her family and demands passports for the children. In the minister's office, she seems to him 'transparent, like a spirit, or a gold-haired Madonna from his long-ago school days' at a mission school. ${ }^{88}$ This image recalls the Marian figures at St Lukes's and is not the last shape that the protean Sylvia is to assume: when the minister hesitates about the passports, she tells him " "that in the country districts people are saying that AIDS is the fault of the government because you've turned out to be such a bunch of crooks". ${ }^{89}$ Ignoring the

inevitable response — that she is repeating " "rumours spread by South African agents" " tells him of the curse laid on her by the children's father. If for a moment she has seemed a

\footnotetext{
${ }^{88}$ Ibid., p. 458.

${ }^{89}$ lbid., p. 459

90 Ibid.
} 
Madonna, the unconcerned ease with which she admits to having been cursed transforms her into 'a little witch' at whom he directs 'panicky glances'. "“Are you cursing me too?" he asks and the passports are issued and delivered. ${ }^{91}$

This succession of narrative moments - and, if they are not as breathless in the original narrative as in my summary, they do follow in rapid succession-can seem to echo a stereotype of white writing about Africa using formulas that have had a long history. In such narratives, abysses of superstition gape beneath the apparently familiar rationality of African leaders, whether they are Kurtz's reversion to an atavistic savagery, Buchan's Reverend John Laputa, or white-authored novels of Zimbabwe's Liberation War. ${ }^{92}$ Yet Lessing departs from this imperial narrative tradition in that she never offers her readers simple moral oppositions, and her insistence on a complex moral world becomes more marked in her later work. Mrs Sussman's Jungian archetypes take many forms and they serve different needs at different stages in people's lives. Lessing constructs Catholicism in The Sweetest Dream as being capable of narrowing our understanding or of providing long perspectives on our humanity, sometimes through the Madonna archetype. But the conclusion of the novel does not allow us to take seriously only the Madonna and to dismiss African spirituality as an irrelevant

\footnotetext{
${ }^{91}$ Ibid., p. 460.

92 For a discussion of these novels see A. Chennells 'Rhodesian Discourse, Rhodesian Novels and the Zimbabwe Liberation War', Society in Zimbabwe's Liberation War Vol II, Ed. Ngwabe Bhebhe and Terence Ranger( Harare: University of Zimbabwe Publications; London: James Currey; Portsmouth NH: Heinemann, 1995), 102-29. Reversion to savagery in a modern state is confirmed a few pages earlier in The Sweetest Dream when the 'Comrade Leader' obeys the summons 'of spirit healers ( $n$ 'gangas, witch-doctors, shamans)', ordinary men and women during the day but who, having 'danced themselves into a trance', now have the authority to issue orders 'that he must kill or throw out the whites or he will displease the ancestors' until he is grovelling and tearful, promising to do better. Next day he issues from 'his fortress house, to plan for his next trip to meet the world's leaders, or a conference with the World Bank' (p. 457). An episode like that is written to a formula but The Sweetest Dream transcends that formula because it refuses to set up easy oppositions between rational secularism which in the colonial novel the metropole controls and how God and the spiritual are understood, which the colonial novel saw as a contest between missionaries and men and women who were empowered by traditional beliefs.
} 
superstition. Sylvia arrives back in Hampstead with the children from Kwandere, introduces them to the Lennoxes currently in the house and then dies in her sleep.

A medical explanation is possible for Sylvia's death: she dies from some malariarelated condition although her convalescence has been more prolonged than malaria normally requires. The curses that precede her departure from Zimlia make it possible, however, to read in her death a sign of their power. If one pursues that possibility, the novel offers agency to the hostile forces traditional religion has the power to unleash. Whether there is, indeed, such an agency is left unclear. To suggest Africa is beyond the reach of European discourse is not of course new. But the manner in which Lessing's novel undermines pretty much all institutional attempts to regulate individual and public lives raises larger issues. What happens when art tries to image the complexity of a reality that it insists is not shaped and governed by discernible social and cultural norms, but by cultural forces that escape normative concepts of rationality? Who, or what, is dreaming?

In an unexpected way, the novel asks these questions by occluding Catholicism. In Kwandere, when Sylvia is certain that AIDS or malaria is the cause of a death, her medical knowledge makes her impatient with whispers of witchcraft. "“[Y]ou are an educated man[...]"' she protests to a local government officer when she has diagnosed AIDS in his wife and he speaks of "“a curse [and] the work of a witch"” whom he can identify. ${ }^{93}$ Rebecca is similarly silenced when she claims that " " all our leaders went bad because we were cursed", 94 for leaving unburied the dead of the war and adds that AIDS is sweeping Kwandere because "“God is angry with us", 95 rejecting Sylvia's patient account of how epidemics have worked in the past and are working now. Science is secure in these

\footnotetext{
93 Ibid., p. 324.

94 Ibid., p.419.

95 Ibid., p.420.
} 
exchanges. But after she has spoken to Rebecca on this last occasion, Sylvia goes to her room, lies on her bed and her glance shifts from 'the crucifix, where the Redeemer hung', then moves over the various pictures of the Virgin as she takes up her rosary. Instead of praying, however, she hangs it back on its hook and looks at the Leonardo print: 'Fish moth had attacked the beautiful faces, the edges of the poster were lace, the children's chubby limbs were blotched' ${ }^{96}$ And then, without comment, Sylvia gets up and goes down to where her patients are waiting. Their enduring presence is not dependent on her beliefs.

That the Virgin Mother displaces Christ the Redeemer seems to hint that, for a moment, Sylvia is recovering the mythic presence which Lessing believed the Church has ignored and which Lessing regarded with more sympathy than she extended to a God who redeems through the torture of the cross. But the Virgin Mother is only a momentary refocusing for Sylvia. The un-prayed rosary and the Leonardo print fading from sight suggest that for Sylvia this mythic presence is no longer accessible and by extension no longer has a place in Kwandere. Father McGuire pronounces the death of St Luke's since the reason for its existence - the people — is no longer present. "'The village will not be here soon. They are leaving because they say the place is cursed". ${ }^{97}$ Science and a religious belief combine briefly in an exchange between Sylvia and the priest but neither can restore life to the village. For Sylvia, "“The devil lurks in the absence of red blood corpuscles"; for Father McGuire, "The devil lurks where there is bad health", ${ }^{98}$ In her loss of faith, Sylvia is doing no more than Sister Molly who will soon leave the convent and will '“'one day[...]say to herself, I'm not a nun. I was never a nun"'. ${ }^{99}$ Father McGuire will move to another mission where a refuge has been established for orphans of AIDS.

\footnotetext{
${ }^{96}$ Ibid., pp. 420-1.

97 Ibid., p. 450.

98 Ibid., pp 451-2.

99 Ibid., p.395.
} 
One of Sylvia's reasons for her only visit to Britain during her years in Zimlia is to get the British press accurately to report what is happening in Zimlia. For the British press, Zimlia and its leaders in the decade immediately after independence can do no wrong. Serious analysis is evaded with clichés. The editor of The Monitor, a force to be reckoned with when it comes to shaping British public opinion, cynically justifies his reasons for not thinking about Zimlia: ““[I]t doesn't do to judge by our standards[...]And it's a completely different culture",. ${ }^{100}$ But the novel allows this to be more than a cynicism that repeats the prejudices of the decade. Instead, it pushes the differences between Zimlia and Britain further than anyone on The Monitor contemplates. Not only do Zimlia's people (from the President downwards) believe in the potential hostility of spiritual forces, but a reading of The Sweetest Dream that traces cause and effect from the curses that directed to Sylvia to her death vindicates their beliefs.

For the purposes of this paper, Catholicism appears to have been displaced from Zimlia as an effective spiritual force and the Church remains present there only as an agency of social and charitable work. If Catholicism was once for Sylvia a sweet dream, it first loses it capacity to beguile and then, in Zimlia at least, loses any effectiveness it may have had as a determining force for good or evil. Sylvia knows that there are areas of indigenous beliefs where she should not attempt to venture. With her death, the novel shows no equivalent hesitation. In allowing witchcraft to be a possible explanation, Lessing is recovering the possibility of an enchanted world. But it is not only Sylvia's death that we (readers who are products of disenchanted modernity) cannot understand. Zimlia itself, perhaps Africa, is written as alien, refusing to be included within totalising discourses whether they are those of Hampstead Communist Comrade Johnny, or the international aid agencies or a Catholic

100 lbid., p. 371. 
Church that will have relevance only if it refuses centuries of centralised control and submits to the authority of other times, places, cultures and peoples. 